\title{
Purification and Properties of Methionyl-Transfer-Ribonucleic Acid Synthetase from Escherichia coli
}

\author{
BY R. L. HEINRIKSON* AND B. S. HARTLEY \\ Medical Research Council Laboratory of Molecular Biology, Cambridge
}

(Received 10 April 1967)

\begin{abstract}
1. Methionyl-t-RNA synthetase (where t-RNA denotes 'soluble' or transfer RNA) has been purified to apparent homogeneity from a ribonuclease I-free strain of Escherichia coli. Polyacrylamide-gel electrophoresis of the final product revealed a single band. The purified enzyme catalyses the exchange of $450 \mu$ moles of pyrophosphate into ATP $/ \mathrm{mg}$. in $15 \mathrm{~min}$. at $37^{\circ}$. 2. Methionyl-t-RNA synthetase is specific for the L-isomer of methionine, but appears to catalyse the methionylation of two distinct species of $t$-RNA, both of which are specific for methionine, but only one of which may be subsequently formylated. 3. The Michaelis constant for L-methionine is $2 \times 10^{-4} \mathrm{M}$ in the ATP- $\mathrm{PP}_{1}$ exchange assay and $2 \times 10^{-5} \mathrm{M}$ for the acylation of t-RNA. 4. Gel filtration of both crude and highly purified preparations of methionyl-t-RNA synthetase on Sephadex G-200 indicates that the active species of enzyme has a molecular weight of about 190000. The amino acid composition of the enzyme is similar to those reported for the isoleucine and tyrosine enzymes from $\boldsymbol{E}$. coli.
\end{abstract}

Aminoacyl-t-RNA $†$ synthetases have a pivotal role in protein biosynthesis in translating the genetic message from nucleotide sequence to amino acid sequence. They accomplish this by virtue of their high specificity towards both amino acids and specific t-RNA species. One might therefore imagine that they would be of great evolutionary stability and would show structural homologies both between species and between different enzymes in a single species. However, chemical investigation must await purification of these enzymes in reasonable quantities. Progress along these lines has been achieved for at least three of the aminoacyl-t-RNA synthetases from Escherichia coli, namely the enzymes specific for isoleucine (Baldwin \& Berg, 1966), tyrosine (Calendar \& Berg, 1966a) and lysine (Stern \& Mehler, 1965).

Of the various aminoacyl-t-RNA synthetases, the enzyme from $E$. coli that is specific for methionine is particularly interesting. Marcker \& Sanger (1964) and Clark \& Marcker (1966) have isolated two distinct methionyl-t-RNA species from $E$. coli,

* Present address: University of Chicago, Argonne Cancer Research Hospital (operated by the University of Chicago for the U.S. Atomic Energy Commission), Chicago, Ill. 60637, U.S.A.

† Abbreviations: t-RNA, 'soluble' or transfer RNA; t-RNA $A_{F}$, the t-RNA that can exist in the formylmethionyl form; t-RNA $A_{m}$, the t-RNA that can exist only in the methionyl form.
t-RNA and t-RNA , one of which (t-RNA $)$ may be formylated subsequent to methionylation. The t-RNA $A_{F}$ appears to incorporate methionine only in the $N$-terminal position of $E$. coli proteins (Clark \& Marcker, 1966), and has been ascribed a role in polypeptide chain initiation in this organism (Clark \& Marcker, 1966; Adams \& Capecchi, 1966; Webster, Engelhardt \& Zinder, 1966). It is therefore of interest to know if there exist in $E$. coli two methionyl-t-RNA synthetases, specific for either t-RNA $A_{F}$ or t-RNA $A_{M}$, or whether a single enzyme accepts both polynucleotides as substrate.

A method for the partial purification of methionylt-RNA synthetase from $E$. coli has been reported by Bergmann (1962). The present paper describes a procedure by which methionyl-t-RNA synthetase may be purified to apparent homogeneity, and some characteristics of the purified enzyme, including evidence suggesting that a single enzyme catalyses the methionylation of both t-RNA $A_{F}$ and t-RNA $A_{M}$.

\section{MATERIALS}

A strain of $E$. coli (M.R.E. 600) grown in continuous cultures and free of ribonuclease $I$ was a gift from the Microbiological Research Establishment, Porton, Wilts. The cells were stored as a paste at $-20^{\circ}$. Hydroxyapatite was prepared by the method of Tiselius, Hjertén \& Levin (1956), and calcium phosphate gel was obtained from Sigma Chemical Co., St Louis, Mo., U.S.A. Crystalline haemoglobin 
was a gift from Mr J. V. Kilmartin, and crystalline yeast alcohol dehydrogenase was given by Mr P. J. G. Butler. $L$ - $\left[{ }^{14} \mathrm{C}\right]$ Methionine and $\mathrm{Na}_{4}{ }^{32} \mathrm{P}_{2} \mathrm{O}_{7}$ were purchased from The Radiochemica] Centre, Amersham, Bucks. t-RNA and t-RNA $A_{\mathbf{m}}$, prepared by countercurrent distribution (Clark \& Marcker, 1966), were kindly provided by Dr B. F. C. Clark.

\section{METHODS}

Isolation of methionyl-t-RNA synthetase. All manipulations were carried out at $0-4^{\circ}$, and all buffers, with the exception of the cell-extract buffer, contained $\mathrm{MgCl}_{2}$ (1.0 mM) and 2-mercaptoethanol (1.5 mM). The potassium salts of the phosphate buffers were employed exclusively.

(a) $100000 \mathrm{~g}$ supernatant. Frozen $E$. coli cells (100g.) were thawed and ground in a chilled mortar with $200 \mathrm{~g}$. of powdered alumina until a smooth white paste had formed. The cell paste was extracted twice with $200 \mathrm{ml}$. portions of $0.01 \mathrm{M}$-tris- $\mathrm{HCl}$ buffer, $\mathrm{pH} 7 \cdot 6$, containing $\mathrm{MgCl}_{2}(0.01 \mathrm{M})$, mercaptoethanol (1.5 mM) and chromatographically pure deoxyribonuclease (Worthington Biochemical Corp., Freehold, N.J., U.S.A.) (1 $\mu \mathrm{g} . / \mathrm{ml}$.). Alumina and cell debris were removed each time by centrifugation for $10 \mathrm{~min}$. at $6000 \mathrm{~g}$ and were finally discarded. The supernatants were combined and centrifuged for $1 \mathrm{hr}$. at $35000 \mathrm{~g}$ and the resulting supernatant was centrifuged for $2 \mathrm{hr}$. at $100000 \mathrm{~g}$.

(b) $\mathrm{pH}$ fractionation. The $\mathrm{pH}$ of the $100000 \mathrm{~g}$ supernatant (345 ml.; $12 \mathrm{mg}$. of protein $/ \mathrm{ml}$.) was adjusted to $5 \cdot 6$ with $\mathrm{N}$-acetic acid, and the solution was centrifuged immediately at $30000 \mathrm{~g}$ for $10 \mathrm{~min}$. The precipitate was discarded and the supernatant was adjusted in a similar manner to $\mathrm{pH} 5 \cdot 0$. After centrifugation as before, the supernatant was discarded and the pellet (1.2g. of protein) was dissolved in $100 \mathrm{ml}$. of 0.1M-tris-HCl buffer, pH8.0.

(c) Ammonium sulphate fractionation. Solid $\left(\mathrm{NH}_{4}\right)_{2} \mathrm{SO}_{4}$ $(17 \cdot 5 \mathrm{~g}$.) was added slowly with stirring to the above solution. After standing $15 \mathrm{~min}$, at $4^{\circ}$, the suspension was centrifuged at $30000 \mathrm{~g}$ for $30 \mathrm{~min}$. The pellet was discarded and $12.5 \mathrm{~g}$. of $\left(\mathrm{NH}_{4}\right)_{2} \mathrm{SO}_{4}$ was added to the clear yellow supernatant. After centrifugation as before, the supernatant was discarded and the pellet was dissolved in $16 \mathrm{ml}$. of $0.01 \mathrm{M}$-trisHCl buffer, pH 8.0.

(d) Calcium phosphate-gel fractionation. The 30-50\%saturated $\left(\mathrm{NH}_{4}\right)_{2} \mathrm{SO}_{4}$ fraction (16 ml.; $344 \mathrm{mg}$. of protein) was diluted to a tota] volume of $160 \mathrm{ml}$. with $5 \mathrm{~mm}$-phosphate buffer, pH7.0. To this solution was added slowly, with stirring, $22 \mathrm{ml}$. of a slurry of calcium phosphate gel in the same buffer (40 mg. dry wt. of gel $/ \mathrm{ml}$.). After stirring for $1 \mathrm{hr}$., the suspension was centrifuged at $15000 \mathrm{~g}$ for $30 \mathrm{~min}$. and the supernatant was discarded. The gel was extracted with $100 \mathrm{ml}$. of $0.03 \mathrm{M}$-phosphate buffer, $\mathrm{pH} 8.0$. After centrifugation as described above, the supernatant was discarded and the enzyme was extracted from the gel with $100 \mathrm{ml}$. of $0 \cdot 12 \mathrm{M}$-phosphate buffer, $\mathrm{pH} 8 \cdot 0$. The extract was centrifuged at $15000 \mathrm{~g}$ for $30 \mathrm{~min}$. and the supernatant was brought to $75 \%$ saturation with $\left(\mathrm{NH}_{4}\right)_{2} \mathrm{SO}_{4}$. The precipitated protein was dissolved in about $4 \mathrm{ml}$. of $0.01 \mathrm{~m}$-tris- $\mathrm{HCl}$ buffer, $\mathrm{pH} 8 \cdot 0$, containing $\mathrm{NaCl}(0 \cdot 1 \mathrm{M})$ in addition to the usual $\mathrm{MgCl}_{2}$ and mercaptoethanol constituents (buffer $\mathbf{A}$ ).

(e) Chromatography on DEAE-Sephadex A-50. The above solution was applied to a column $(33 \mathrm{~cm} . \times 1 \cdot 7 \mathrm{~cm}$. diam.) of Sephadex G-25 equilibrated with buffer $A$ to remove the remaining $\left(\mathrm{NH}_{4}\right)_{2} \mathrm{SO}_{4}$. The protein breakthrough (13.8 ml.; $51 \mathrm{mg}$. of protein) was applied to a column
$(18 \mathrm{~cm} . \times 1.5 \mathrm{~cm}$. diam.) of DEAE-Sephadex A-50 that had been washed and equilibrated first with M-tris-HCl buffer, pH 8.0, and then with buffer $A$ as described by Peterson \& Sober (1962). The sample was washed in with $50 \mathrm{ml}$. of buffer $\mathrm{A}$ and eluted with a linear gradient of $\mathrm{NaCl}$ in buffer $\mathrm{A}$ $\left(600 \mathrm{ml}\right.$.; $\left.0.10-0.50 \mathrm{M}-\mathrm{Cl}^{-}\right)$at a flow rate of $40 \mathrm{ml} . / \mathrm{hr}$., $8.0 \mathrm{ml}$. fractions being collected. The protein concentration in the effluent fractions was determined by measuring $E_{280}$ and enzyme assays were conducted as described below.

(f) Chromatography on hydroxyapatite. The fractions from step (e) that had the highest specific activities were pooled and the solution, containing $5.7 \mathrm{mg}$. of protein, was added to a column $(4 \mathrm{~cm} . \times 1.5 \mathrm{~cm}$. diam.) of hydroxyapatite that had been equilibrated with $5 \mathrm{~mm}$-phosphate buffer, pH 7.8, containing $\mathrm{MgCl}_{2}$ (1 $\mathrm{mM}$ ) and 2-mercaptoethanol ( $1.5 \mathrm{~mm})$. The column was washed with $0.05 \mathrm{M}$-phosphate buffer, pH 7.8, until the effluent was free of materia] absorbing at $280 \mathrm{~m} \mu$ and then eluted with a linear gradient of phosphate $(200 \mathrm{ml}$; $0 \cdot 05-0 \cdot 12 \mathrm{M}, \mathrm{pH} 7 \cdot 8)$. The flow rate was $15 \mathrm{ml} . / \mathrm{hr}$., and $4.0 \mathrm{ml}$. fractions were collected and assayed for protein and enzyme activity.

(g) Gel filtration on Sephadex G-200. The gel was allowed to swell for 1 week in $0.01 \mathrm{M}$-tris-HCl buffer at pH 8.0, after which time fine particles were removed by several decantations in the same buffer system.

A column $(48 \mathrm{~cm} . \times 0.9 \mathrm{~cm}$. diam.) of the gel was poured and equilibrated with the same buffer. The enzyme preparation obtained in step $(f)$ was concentrated by ultrafiltration as described by Crestfield, Stein \& Moore (1963) and finally obtained in a volume of $0.5-1.0 \mathrm{ml}$. This sample was added to the column, and $1 \mathrm{ml}$. fractions were collected and analysed for protein and activity. The flow rate was about 2-3 ml./hr.

Polyacrylamide-gel electrophoresis. Purified preparations of the enzyme were subjected to electrophoresis in polyacrylamide gels by the method described by Davis (1962). Electrophoresis was carried out at room temperature for $2.5 \mathrm{hr}$. at $4 \mathrm{~ms} /$ tube. Proteins were fixed and stained with a $1 \%$ solution of Amido Schwartz in $7 \%(v / v)$ acetic acid and the gels were electrophoretically destained.

Enzyme assays. (a) ATP-[ $\left.{ }^{32} \mathrm{P}\right] \mathrm{PP}_{1}$ exchange assay. This was carried out essentially as described by Bergmann (1962) except that the $\mathrm{pH}$ was 8.5 and the solutions contained 2-mercaptoethanol $(0.01 \mathrm{~m})$. After addition of enzyme, $200 \mu$ l. samples were withdrawn at intervals and added, with rapid mixing, to $5 \mathrm{ml}$. test tubes containing $100 \mu \mathrm{l}$. of $7 \%(w / v) \mathrm{HClO}_{4}$ and $50 \mu \mathrm{l}$. of a $15 \%$ suspension of Norit $\mathrm{A}$ in water. Effluent fractions from preparative columnchromatographic procedures were assayed by adding $5 \mu \mathrm{l}$. portions to tubes containing $200 \mu \mathrm{l}$. of stock assay solution at $37^{\circ}$; reactions were terminated by the addition of $\mathrm{HClO}_{4}$ and Norit $\mathrm{A}$ as described above. After 5-10 min., the charcoal was filtered off with the aid of mild suction on $2.0 \mathrm{~cm}$. glass-paper filter disks (Whatman GF/c) and washed thoroughly with about $50 \mathrm{ml}$. of water. The filter disks were then glued to planchets and dried for $10 \mathrm{~min}$. at $60^{\circ}$, and the radioactivity was determined with a NuclearChicago gas-flow counter (model 186A). Controls lacking methionine were performed in all the time-course assays of impure preparations. One unit of activity is defined as the exchange of $1 \mu$ mole of [ $\left.{ }^{32} \mathrm{P}\right] \mathrm{PP}_{1}$ with ATP in $15 \mathrm{~min}$. at $37^{\circ}$.

(b) Acylation assay. The reaction mixtures contained $100 \mu$ moles of tris $-\mathrm{HCl}$ at $\mathrm{pH} 8 \cdot 5,5 \mu$ moles of ATP, $15 \mu$ moles of $\mathrm{MgCl}_{2}, 50 \mu$ moles of 2 -mercaptoethanol, $2.5 \mathrm{mg}$. of crude 
t-RNA (General Biochemicals Inc., Chagrin Falls, Ohio, U.S.A.), $0 \cdot 134 \mu$ mole of $\left[{ }^{14} \mathrm{C}\right]$ methionine $(6 \cdot 28 \mu \mathrm{d} / \mu \mathrm{mole}$; $3 \times 10^{6}$ counts $/ \mathrm{min} . / \mu \mathrm{mole}$ ) and enzyme in a total volume of $1.0 \mathrm{ml}$. Reactions were carried out at $37^{\circ}$ and analyses were performed on $100 \mu$ l. samples withdrawn at various times and mixed with 3-4 ml. of a chilled solution of $5 \%(w / v)$ trichloroacetic acid and $3 \%(w / v)$ casein hydrolysate (Difco 'casamino acids'). As in the exchange assay, effluent fractions were assayed by adding $5 \mu \mathrm{l}$. portions to $100 \mu \mathrm{l}$. of stock assay solution incubated at $37^{\circ}$, and the reactions were terminated by the addition of 3-4 ml. of the trichloroacetic acid solution. After $10 \mathrm{~min}$., the labelled t-RNA precipitate was collected on a paper filter disk as described above and washed first with $20-30 \mathrm{ml}$. of the cold trichloroacetic acid solution and finally with about $5 \mathrm{ml}$. of etherethanol $(1: 1, \nabla / v)$. The disks were glued to planchets and dried as described above before being counted. In this assay system, 1 unit of methionyl-t-RNA synthetase activity is the amount of enzyme that catalyses the incorporation of $1 \mathrm{~m} \mu$ mole of methionine into methionyl-tRNA/min.

(c) Alcohol dehydrogenase assay. Yeast alcohol dehydrogenase was assayed as described by Racker (1955).

Protein determinations. Protein estimations were made both spectrophotometrically (Layne, 1957) and by the method of Lowry, Rosebrough, Farr \& Randall (1951).

Amino acid analyses. The enzyme sample ( $1.4 \mathrm{mg}$.) was concentrated by ultrafiltration (Crestfield et al. 1963) and finally obtained in water by gel filtration on a column $(30 \mathrm{~cm} . \times 2 \mathrm{~cm}$. diam.) of Sephadex G-25. After being freezedried, the enzyme was oxidized with performic acid as described by Moore (1963). The oxidized protein was again freeze-dried, divided into three portions and subjected to hydrolysis in vacuo at $110^{\circ}$ for 15,39 and $63 \mathrm{hr}$. in $6 \mathrm{~N}-\mathrm{HCl}$. The hydrolysates were analysed with a Beckman model 120C amino acid analyser. Tryptophan was estimated spectrophotometrically (Beaven \& Holiday, 1952).

\section{RESULTS}

Enzyme purification. The purification of methionyl-t-RNA synthetase from $100 \mathrm{~g}$. of $E$. coli is summarized in Table 1 . The specific activity of the purified enzyme was about 290 times that of the $100000 \mathrm{~g}$ supernatant and the overall yield was $11 \%$. As shown in Table 1, the ratio of the specific activities for the acylation of t-RNA and the ATP- $\mathrm{PP}_{1}$ exchange reaction is fairly constant throughout the purification. The most highly purified preparation catalysed the exchange of $450 \mu$ moles of $\left[{ }^{32} \mathrm{P}\right] \mathrm{PP}_{\mathrm{i}} / \mathrm{mg}$. in $15 \mathrm{~min}$. at $37^{\circ}$.

The initial stages of the purification were straightforward; the enzyme was precipitated in the $\mathrm{pH}$ interval 5.5-5.0 and between 30 and $50 \%$ saturation with ammonium sulphate. Batchwise absorption of the enzyme by calcium phosphate gel was found to be most efficient at low ionic strength and at $\mathrm{pH} 7 \cdot 0$, and the recovery of activity from the gel was about $60 \%$. The final steps in the purification utilized column-chromatographic techniques. Methionyl-t-RNA synthetase is weakly bound to DEAE-Sephadex at $\mathrm{pH} 8 \cdot 0$, and, under the conditions employed, was one of the first of the step $(d)$ constituents to emerge from the column (Fig. 1). This step therefore afforded a substantial purification of the enzyme from the more strongly bound protein and nucleic acid contaminants, and yielded a preparation that was about $30-40 \%$ pure. Chromatography of this preparation on columns of hydroxyapatite in the manner described above gave a single peak of protein that was coincident with the methionyl-t-RNA synthetase activity (Fig. 2). The specific activity across the peak was constant at a value of about 350 for the exchange assay, but polyacrylamide-gel electrophoresis of samples removed at various times during the elution of the enzyme revealed both a major and a minor component. When the enzyme purified on hydroxyapatite was subjected to gel filtration on Sephadex G-200, the minor component appeared on the trailing edge of the activity peak (Fig. 3). Polyacrylamide-gel electrophoresis of samples across the peak revealed a single band (samples $a, b$ and $c$;

\section{Table 1. Purification of methionyl-t-RNA synthetase from E. coli}

All preparations were assayed by both the ATP-PP exchange reaction and by the acylation of t-RNA with ${ }_{\mathrm{L}}-\left[{ }^{14} \mathrm{C}\right]$ methionine. Details pertaining to the purification scheme and the assay procedures are presented in the Methods section. The activities are expressed as $\mu$ moles of $P P_{1}$ exchanged $/ 15 \mathrm{~min} . / \mathrm{mg}$. of protein for the exchange assay, and as $\mathrm{m} \mu$ moles of methionine incorporated into methionyl-t-RNA/min./mg. of protein for the acylation assay.

\begin{tabular}{|c|c|c|c|c|c|}
\hline \multirow[b]{2}{*}{ Fraction } & \multirow{2}{*}{$\begin{array}{l}\text { Protein } \\
\text { (mg.) }\end{array}$} & \multicolumn{2}{|c|}{ Sp. activity } & \multirow{2}{*}{$\begin{array}{c}\text { Relative } \\
\text { purification }\end{array}$} & \multirow[b]{2}{*}{$\begin{array}{l}\text { Yield } \\
(\%)\end{array}$} \\
\hline & & Exchange & Acylation & & \\
\hline (a) $100000 \mathrm{~g}$ supernatant & 4140 & 1.56 & $3 \cdot 8$ & 1 & 100 \\
\hline (b) $\mathrm{pH} 5 \cdot 5-5 \cdot 0$ & 1200 & $3 \cdot 44$ & $7 \cdot 8$ & 2 & 63.5 \\
\hline (c) $30-50 \%$-satd. $\left(\mathrm{NH}_{4}\right)_{2} \mathrm{SO}_{4}$ & 344 & $9 \cdot 52$ & $23 \cdot 0$ & 6 & 50.5 \\
\hline (d) Calcium phosphate & 53 & $36 \cdot 0$ & $84 \cdot 3$ & 23 & $29 \cdot 5$ \\
\hline (e) DEAE-Sephadex & $5 \cdot 7$ & 172 & 393 & 110 & $15 \cdot 1$ \\
\hline (f) Hydroxyapatite & $2 \cdot 5$ & 360 & 820 & 230 & $13 \cdot 0$ \\
\hline (g) Sephadex G-200 & $1 \cdot 8$ & 450 & 980 & 288 & $11 \cdot 5$ \\
\hline
\end{tabular}




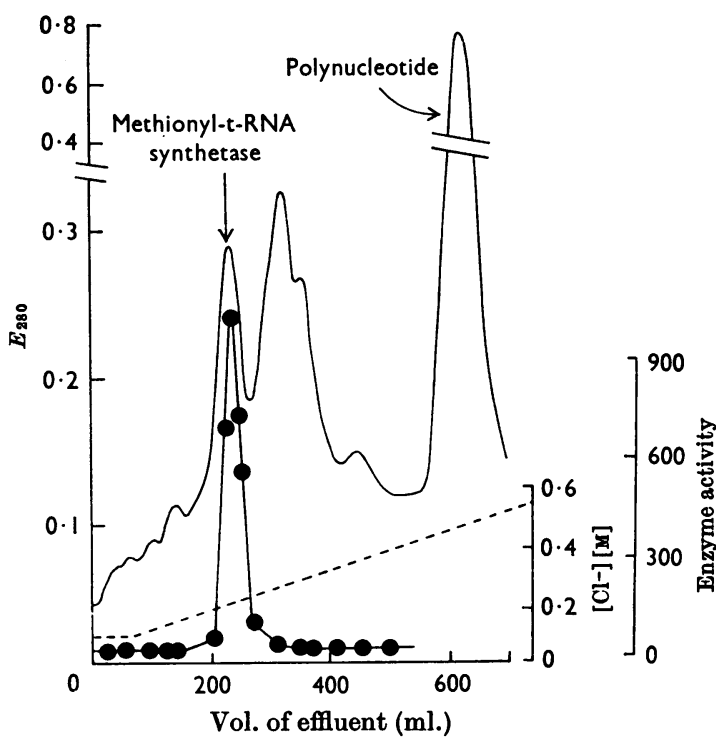

Fig. 1. Chromatography of the calcium phosphate-gel extract on DEAE-Sephadex A-50. The sample containing $51 \mathrm{mg}$. of protein was added to a column $(18 \mathrm{~cm} . \times 1.5 \mathrm{~cm}$. diam.) of the exchanger, followed by about $50 \mathrm{ml}$. of $0.01 \mathrm{M}$ tris- $\mathrm{HCl}$ buffer, $\mathrm{pH} 8 \cdot 0$, containing $\mathrm{NaCl}(0 \cdot 1 \mathrm{M}), \mathrm{MgCl}_{2}$ (1 $\mathrm{mM})$ and 2-mercaptoethanol (1.5 mM). Elution was continued with a linear gradient of $\mathrm{NaCl}$ as described in the Methods section. Enzyme activity is expressed as the number of counts/min. of $\left[{ }^{14} \mathrm{C}\right]$ methionine incorporated into t-RNA by $5 \mu$ l. of effluent $/ 100 \mu$ l. of assay solution $/ \mathrm{min}$. -—, Methionyl-t-RNA synthetase activity; - $-\boldsymbol{E}_{280}$; $-\ldots, \mathrm{NaCl}$ gradient.

Fig. 3) except on the trailing edge, where a band corresponding to the minor contaminant was visible (sample $d$; Fig. 3). The purified enzyme was devoid of any other aminoacyl-t-RNA synthetase activity as measured by the exchange assay.

In the initial stages of the purification, up to and including the calcium phosphate-gel absorption step, the various enzyme preparations could be stored indefinitely at $-20^{\circ}$ without appreciable loss of activity. On the other hand, the enzyme solutions obtained from the final column-chromatographic steps were rapidly inactivated by freezing, even in the presence of higher concentrations of mercaptoethanol. These enzyme preparations were stored at $4^{\circ}$ in $0.01 \mathrm{M}$-mercaptoethanol, under which conditions full activity was retained for 1-2 weeks. Thereafter the activity fell off gradually, with a half-life of about 1-2 months.

Some properties of methionyl-t-RNA synthetase. Methionyl-t-RNA synthetase varies little in activity over the rather broad $\mathrm{pH}$ range $7 \cdot 5-9$, but exhibits a slight optimum at pH8.5. As shown in Fig. 4, the

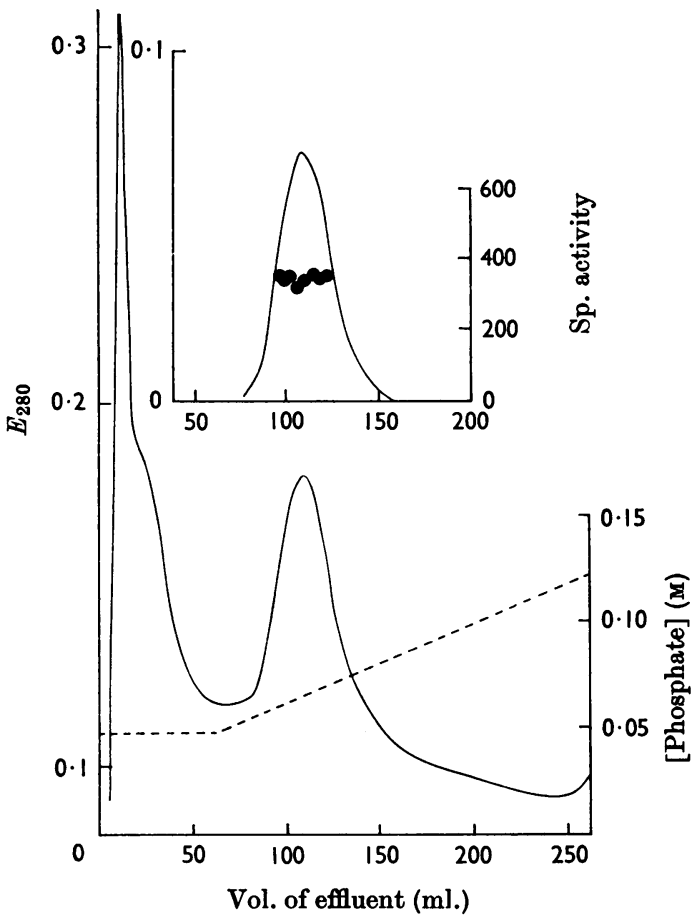

Fig. 2. Chromatography of methionyl-t-RNA synthetase on hydroxyapatite. The sample containing 5-6 mg. of protein was added to a column $(4 \mathrm{~cm} . \times 1.5 \mathrm{~cm}$. diam.) of hydroxyapatite, followed by $60 \mathrm{ml}$. of $0.05 \mathrm{M}$-potassium phosphate buffer, $\mathrm{pH} 7 \cdot 8$, containing $\mathrm{MgCl}_{2}$ (1 mM) and 2-mercaptoethanol (1.5 mM). Elution was continued with a linear gradient of $0.05-0.12 \mathrm{M}$-phosphate as described in the Methods section. The insert is a plot of the effluent curve corrected for the base line. Specific activities were determined by the ATP-PP $\mathbf{1}_{1}$ exchange assay. 0 , Specific methionyl-t-RNA synthetase activity; - $-E_{280}$; ----, phosphate gradient.

enzyme is specific for the L-isomer of methionine. The Michaelis constants for L-methionine are $2 \times 10^{-4} \mathrm{M}$ and $2 \times 10^{-5} \mathrm{M}$ respectively for the ATP$\mathrm{PP}_{\mathrm{i}}$ exchange and t-RNA acylation assays (see Fig. 5).

Acylation of $t-R N A_{\mathrm{F}}$ and $t-R N A_{\mathrm{M}}$. The most highly purified preparation of enzyme obtained by gel filtration on Sephadex G-200 was incubated with the standard acylation assay system described in the Methods section except that the crude t-RNA was replaced by either t-RNA $A_{F}$ or t-RNA $A_{M}$. Each of these polynucleotide preparations was shown to be free of the other t-RNA, although they were only about $20 \%$ pure. As shown in Fig. 6, methionyl-t-RNA-synthetase catalyses the acylation of both of the t-RNA species with [14C]methionine. 


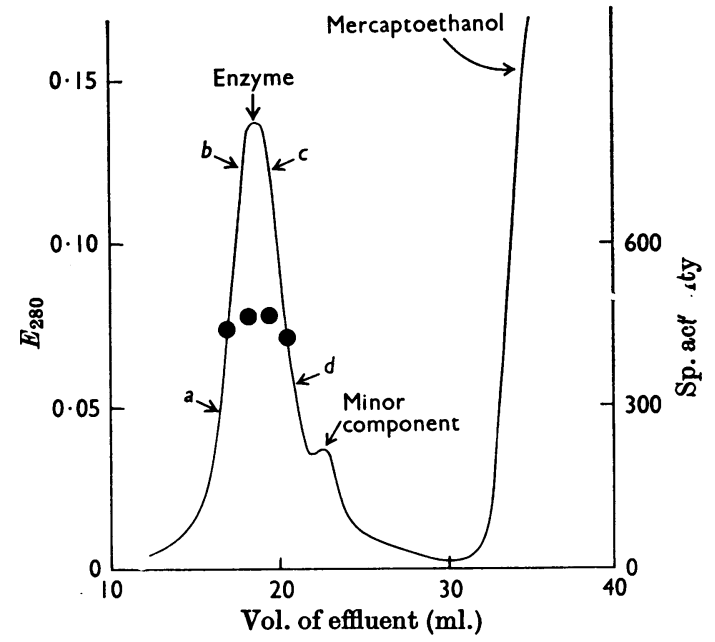

Fig. 3. Gel filtration of methionyl-t-RNA synthetase on Sephadex G-200. The column (48cm. $\times 0.9 \mathrm{~cm}$. diam.) was equilibrated with $0.01 \mathrm{M}$-tris-HCl buffer, $\mathrm{pH} 8 \cdot 0$, containing $\mathrm{MgCl}_{2}$ (1 mM) and 2-mercaptoethanol (1.5 mM) and was operated at a flow rate of $2-3 \mathrm{ml} . / \mathrm{hr}$. Specific activities were determined by the ATP-PP $\mathbf{P}_{1}$ exchange assay. $\bullet$, Specific methionyl-t-RNA synthetase activity; - $-E_{280}$. Samples $(100 \mu l$.) were removed from a column of the fraction designated $a-d$ and were subjected to electrophoresis on polyacrylamide gels as described in the Methods section.

Molecular weight. Because of the small quantities of pure enzyme available, the molecular weight of the enzyme was determined by gel filtration on Sephadex G-200. Elution profiles obtained from the gel filtration of mixtures containing pure or crude enzyme together with yeast alcohol dehydrogenase and haemoglobin markers are presented in Figs. $7(a)$ and $7(b)$. As shown in Fig. 7(a), pure methionyl-t-RNA synthetase emerges ahead of the alcohol dehydrogenase on the Sephadex G-200 column. So also does the crude enzyme (Fig. 7b). In neither case was a second peak of activity discernible. By plotting the elution volume of the marker components against their known molecular weights (Andrews, 1965) a value of about 190000 was estimated for the molecular weight of methionyl-tRNA synthetase.

Amino acid analysis. The results obtained from the amino acid analysis of highly purified methionylt-RNA synthetase subjected to acid hydrolysis for 15,39 and $63 \mathrm{hr}$. are presented in Table 2. The number of residues/molecule was calculated on the basis of a molecular weight of 100000 for ease of comparison with the values reported for the isoleucine (Baldwin \& Berg, 1966) and tyrosine (Calendar \& Berg, 1966a) enzymes from $E$. coli. Spectrophotometric analysis revealed that the tyrosine/tryptophan ratio was about 45 . However,

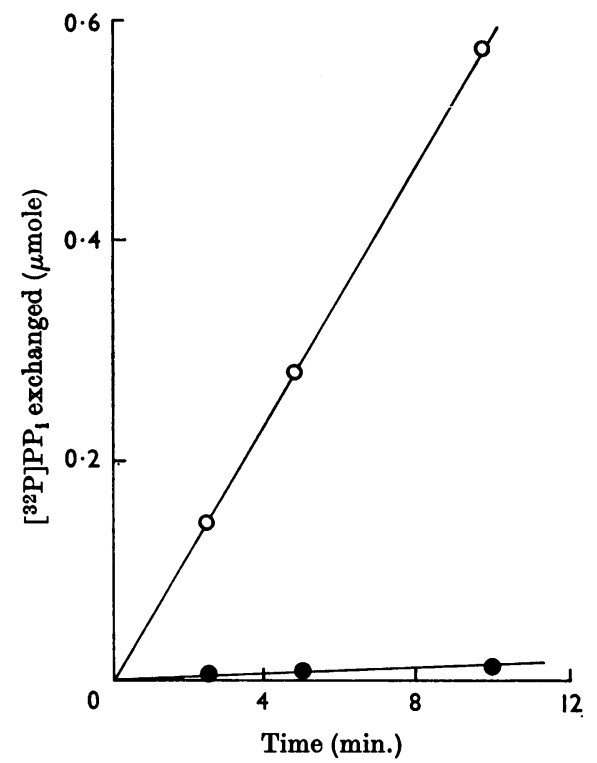

Fig. 4. Specificity of methionyl-t-RNA synthetase for Lmethionine. Two reaction mixtures were prepared, each containing $100 \mu$ moles of tris-HCl, $\mathrm{pH} 8 \cdot 5,5 \mu$ moles of $\mathrm{MgCl}_{2}, 10 \mu$ moles of $\mathrm{KF}, 2 \mu$ moles of ATP, $2 \mu$ moles of [32P] $P_{1}(150000$ counts $/ \mathrm{min} . / \mu$ mole) and $10 \mu$ moles of 2 mercaptoethanol in a total volume of $1.0 \mathrm{ml}$. To one solution was added $50 \mu \mathrm{l}$. of $1 \mathrm{mM}-\mathrm{L}$-methionine (O), and to the other an equal volume of $1 \mathrm{~mm}-\mathrm{m}-\mathrm{methionine} \mathrm{(0).}$ Reactions were initiated by the addition of $20 \mu$ l. of highly purified enzyme $(0.05 \mathrm{mg} . / \mathrm{ml}$.) and, at the times indicated, $200 \mu l$. samples were analysed for labelled ATP as described in the Methods section.

since the tyrosine was apparently lost during the analysis, probably owing to chlorination, uncertainty exists as to the quantities of these amino acids present in the enzyme.

\section{DISCUSSION}

The present paper describes a method for the purification of methionyl-t-RNA synthetase from $E$. coli, as well as some of the properties of the purified enzyme. Methionyl-t-RNA synthetase catalyses both the synthesis of methionyl-t-RNA and the methionine-dependent exchange of $P_{1}$ and ATP. The purified enzyme catalyses the exchange of $450 \mu$ moles of $P P_{i} / \mathrm{mg}$. at $37^{\circ}$ in $15 \mathrm{~min}$. This value compares favourably with the corresponding values for the other three $E$. coli aminoacyl-t-RNA synthetases that have been purified to date, namely 650 for the isoleucine enzyme (Baldwin \& Berg, 1966), 312 for the lysine enzyme (Stern \& Mehler, 1965) and about 660 for the tyrosine enzyme (Calendar \& Berg, 1966a). Assuming a molecular 


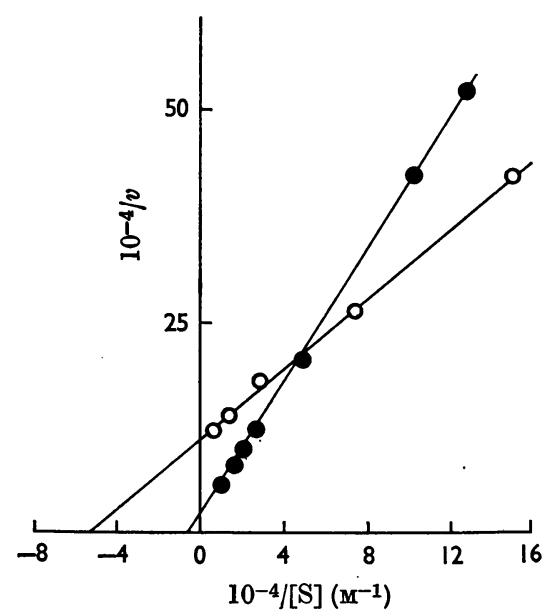

Fig. 5. Lineweaver \& Burk (1934) plots of the acylation reaction (O) and the $A T P-P_{1}$ exchange reaction with L-methionine as substrate (๑). Reaction mixtures were prepared as described in the Methods section with methionine at the indicated concentration and containing $1 \cdot 25 \mu \mathrm{g}$. of highly purified enzyme/ml. of solution. Each point represents the initial rate of reaction under the conditions specified. For the acylation assay (O), arbitrary velocity units are employed. In the exchange reaction (0), velocity is defined as the number of $\mu$ moles of $\mathrm{PP}_{1}$ exchanged in $15 \mathrm{~min} . / \mathrm{mg}$. of protein.

weight of 190000 for methionyl-t-RNA synthetase, its specific activity as determined by the acylation assay is about 185 moles of methionine incorporated/ mole of enzyme/min., a value roughly comparable with those reported by Makman \& Cantoni (1965) for purified yeast seryl- and phenylalanyl-t-RNA synthetase (50 and 100 respectively). Other aminoacyl-t-RNA synthetases that have been isolated in a homogeneous state include the tyrosine enzyme from pancreas (Schweet \& Allen, 1958; Clark \& Eyzaguire, 1962) and the alanine enzyme from pig liver (Webster, 1961).

The stability of methionyl-t-RNA synthetase is dependent on the presence of mercaptoethanol. A similar observation has been reported for the methionine enzyme from wheat germ (Moustafa, 1964) and it was suggested that a reduced thiol group might be involved in the catalytic process. Although the stability dependence on mercaptoethanol displayed by many of the aminoacyl-t-RNA synthetases suggests that an active-site cysteine residue might be a common feature of these enzymes, at least two of the synthetases, namely lysyl- (Stern \& Mehler, 1965) and alanyl-t-RNA synthetase (Webster, 1961), do not require a reducing medium for stability, and indeed may be inactivated by mercaptoethanol.

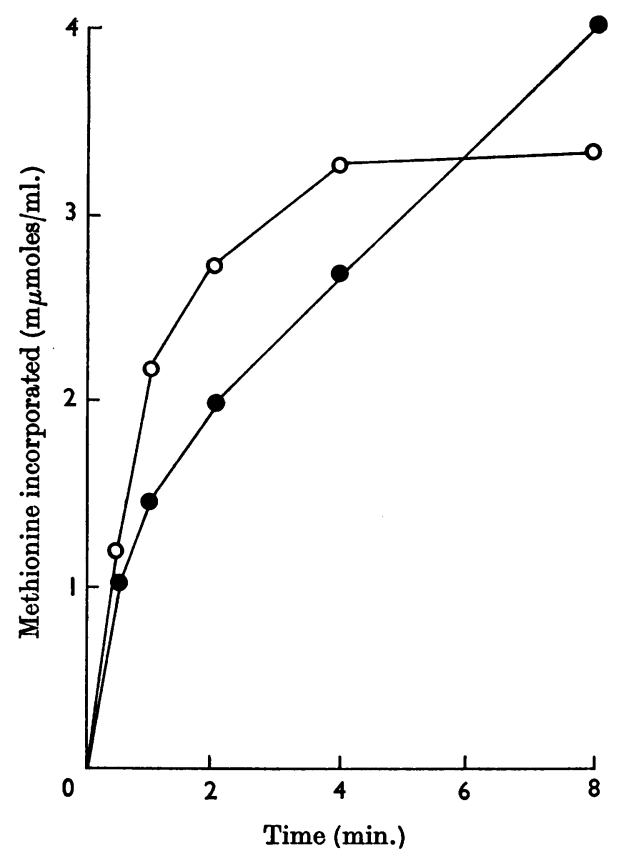

Fig. 6. Methionylation of t-RNA The reaction mixtures contained, in a volume of $1.0 \mathrm{ml}$., $100 \mu$ moles of tris $-\mathrm{HCl}, \mathrm{pH} \mathrm{8 \cdot 5,5} \mu$ moles of $\mathrm{MgCl}_{2}, 50 \mu$ moles of 2-mercaptoethanol, $0 \cdot 134 \mu$ mole of [ $\left.{ }^{14} \mathrm{C}\right]$ methionine $\left(3 \times 10^{6}\right.$ counts $/ \mathrm{min} . / \mu$ mole $)$ and $1.25 \mu \mathrm{g}$. of highly purified methionyl-t-RNA synthetase. The t-RNA $A_{F}$ and t-RNA reaction mixtures contained $1 \mathrm{mg}$. and $1.5 \mathrm{mg}$. of polynucleotide respectively. Analyses for labelled poly. nucleotide were made on $100 \mu \mathrm{l}$. portions at the times indicated as described in the Methods section.

Unlike the tyrosine enzyme from $\boldsymbol{E}$. coli (Calendar \& Berg, 1966b), which catalyses the activation and subsequent transfer of both $D$ - and L-tyrosine to t-RNA, methionyl-t-RNA synthetase is specific for the L-isomer of methionine. The Michaelis constants for L-methionine are $2 \times 10^{-4} \mathrm{M}$ for the exchange assay and $2 \times 10^{-5} \mathrm{M}$ for the acylation reaction, and are higher than the corresponding values for the lysine enzyme (Stern \& Mehler, 1965). The intermediate methionyl-t-RNA synthetase-methionyladenylate complex formed in appropriate reaction mixtures in the absence of acceptor t-RNA may be isolated by gel filtration on columns of Sephadex G-25, but further studies on the complex have not been carried out (R. L. Heinrikson, unpublished work).

One of the purposes of this investigation was to determine whether there are one or two methionylt-RNA synthetases for the acylation of the two distinct species of methionine-specific t-RNA present in $E$. coli. The results obtained with 


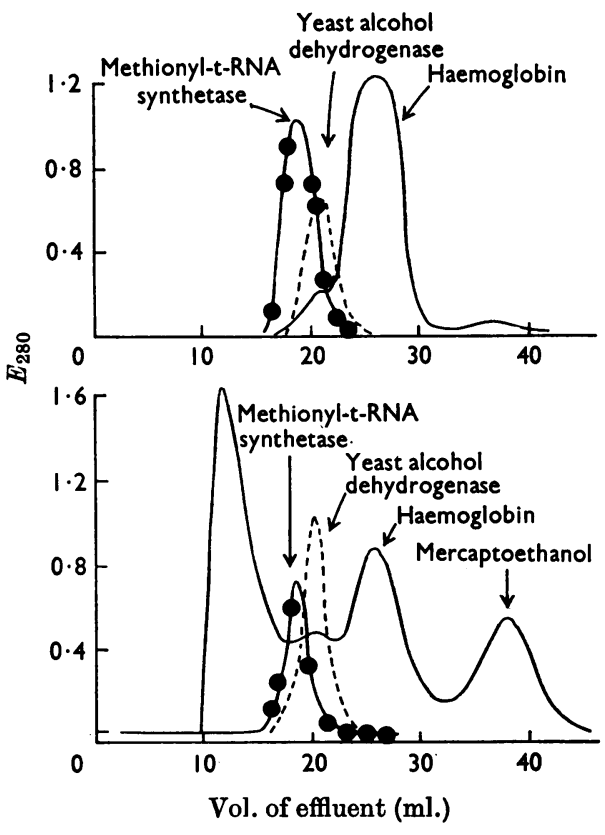

Fig. 7. Estimation of the molecular weight of methionyl-tRNA synthetase by gel filtration on Sephadex G-200. Samples were applied to a column $(48 \mathrm{~cm} . \times 0.9 \mathrm{~cm}$. diam.) of Sephadex G-200 equilibrated with 0.01 M-2-mercaptoethanol and elution was continued with the same buffer at a flow rate of $2 \mathrm{ml} . / \mathrm{hr}$. Effluent curve (a) was obtained from a sample consisting of $100 \mu \mathrm{g}$. of pure methionyl-t-RNA synthetase, $600 \mu \mathrm{g}$. of haemoglobin and $1 \mathrm{mg}$. of yeast alcohol dehydrogenase in a total volume of $0.6 \mathrm{ml}$. The sample for curve (b) contained approx. $1 \mathrm{mg}$. of protein from the calcium phosphate step with a specific activity of about $20,2 \mathrm{mg}$. of yeast alcohol dehydrogenase and $200 \mu \mathrm{g}$. of haemoglobin in the same volume. Fractions were assayed for both methionyl-t-RNA synthetase activity and alcohol dehydrogenase activity as described in the Methods section. Enzyme activities are expressed in arbitrary units for clarity of presentation. $-\longrightarrow$, Methionyl-t-RNA synthetase activity; ----, alcohol dehydrogenase activity; $\longrightarrow, E_{280}$.

purified methionyl-t-RNA synthetase are consistent with the hypothesis that one enzyme catalyses the acylation of both t-RNA $A_{M}$ and t-RNA , although it is not possible to exclude rigorously the presence of another enzyme not detected by the techniques employed. Similar considerations for isoleucyl-tRNA synthetase have been discussed by Baldwin \& Berg (1966).

The molecular weight of methionyl-t-RNA synthetase was estimated to be about 190000 . This value was determined rather crudely from the behaviour of the enzyme on a column of Sephadex G-200. However, both the highly purified enzyme and an impure preparation emerged at exactly the
Table 2. Amino acid analysis of methionine-t-RNA synthetase

Details for the analysis are presented in the Methods section. Each analysis was performed on about $0.4 \mathrm{mg}$. of performic acid-oxidized protein. Values for serine and threonine are corrected for destruction during the hydrolysis, and those for valine and isoleucine are corrected to $80 \mathrm{hr}$. hydrolysis.

Amino acid composition

$\overbrace{\text { At } 15 \mathrm{hr} \text {. At } 39 \mathrm{hr} \text {. At } 63 \mathrm{hr} .}^{\begin{array}{c}\text { (residues } / \\ \text { mol. of } \\ \text { mol.wt. } \\ 100000\end{array}}$

\begin{tabular}{|c|c|c|c|c|}
\hline Lysine & 67.8 & & 70.5 & $43 \cdot 3$ \\
\hline Histidine & $35 \cdot 0$ & & $35 \cdot 6$ & $22 \cdot 1$ \\
\hline Arginine & $59 \cdot 5$ & & $56 \cdot 0$ & $36 \cdot 1$ \\
\hline Cysteic acid & 16.9 & 16.9 & & $10 \cdot 6$ \\
\hline $\begin{array}{l}\text { Aspartic acid } \\
\text { + asparagine }\end{array}$ & 157 & 159 & 156 & $98 \cdot 1$ \\
\hline $\begin{array}{l}\text { Methionine } \\
\text { sulphone }\end{array}$ & 28.8 & $29 \cdot 6$ & $29 \cdot 6$ & $18 \cdot 2$ \\
\hline Threonine & $66 \cdot 0$ & $62 \cdot 5$ & 60.5 & $44 \cdot 0$ \\
\hline Serine & $81 \cdot 5$ & 72.9 & $67 \cdot 5$ & $54 \cdot 4$ \\
\hline $\begin{array}{l}\text { Glutamic acid } \\
\text { + glutamine }\end{array}$ & 167 & 160 & 162 & 101.9 \\
\hline Proline & $65 \cdot 5$ & $64 \cdot 7$ & $66 \cdot 0$ & 40.9 \\
\hline Glycine & 115 & 112 & 111 & 70.5 \\
\hline Alanine & 133 & 129 & 130 & 81.9 \\
\hline Valine & $77 \cdot 0$ & $84 \cdot 7$ & $89 \cdot 0$ & $57 \cdot 5$ \\
\hline Isoleucine & $65 \cdot 0$ & $69 \cdot 5$ & $71 \cdot 7$ & $45 \cdot 6$ \\
\hline Leucine & (115) & (115) & 115 & 71.9 \\
\hline Tyrosine & Nil & Nil & & ? \\
\hline Phenylalanine & 65.9 & $67 \cdot 1$ & $68 \cdot 1$ & $43 \cdot 0$ \\
\hline
\end{tabular}

same elution volume, just ahead of the yeast alcohol dehydrogenase marker. No other active peaks were discernible by the assay technique, which would have detected $5 \%$ of the observed activity. Since the molecular weights of most of the aminoacyl-tRNA synthetases thus far studied seem to be about 100000 (for references see Baldwin \& Berg, 1966), it is possible that the methionine enzyme may exist as a dimer or aggregate. If this is the case, the monomer-dimer equilibrium must lie far in the direction of dimer, for no monomer activity was detected.

Except for tyrosine and tryptophan, which were not estimated for reasons discussed above, the amino acid analysis of methionyl-t-RNA synthetase parallels roughly those that have been published for the enzymes for isoleucine (Baldwin \& Berg, 1966) and tyrosine (Calendar \& Berg, 1966a) in E. coli.

The expert technical assistance of Mr David Elton is gratefully acknowledged. 


\section{REFERENCES}

Adams, J. M. \& Capecchi, M. R. (1966). Proc. nat. Acad. Sci., Wash., 55, 147.

Andrews, P. (1965). Biochem. J. 96, 595.

Baldwin, A. N. \& Berg, P. (1966). J. biol. Chem. 241, 831.

Beaven, G. H. \& Holiday, E. R. (1952). Advanc. Protein Chem. 7, 319.

Bergmann, F. H. (1962). In Methods of Enzymology, vol. 5, p. 708. Ed. by Colowick, S. P. \& Kaplan, N. O. New York: Academic Press Inc.

Calendar, R. \& Berg, P. (1966a). Biochemistry, 5, 1681.

Calendar, R. \& Berg, P. (1966b). Biochemistry, 5, 1690.

Clark, B. F. C. \& Marcker, K. A. (1966). J. molec. Biol. 17, 394.

Clark, J. M., jun. \& Eyzaguire, J. P. (1962). J. biol. Chem. 237, 3698.

Crestfield, A. M., Stein, W. H. \& Moore, S. (1963). J. biol. Chem. 288, 618.

Davis, B. J. (1962). Disc Electrophoresis, part II. Rochester, N.Y.: Distillation Products Inc.

Layne, E. (1957). In Methods of Enzymology, vol. 3, p. 451. Ed. by Colowick, S. P. \& Kaplan, N. O. New York: Academic Press Inc.
Lineweaver, H. \& Burk, D. (1934). J. Amer. chem. Soc. 56, 658.

Lowry, O. H., Rosebrough, N. J., Farr, A. L. \& Randall, J. R. (1951). J. biol. Chem. 193, 265.

Makman, M. H. \& Cantoni, G. L. (1965). Biochemistry, 4, 1434.

Marcker, K. A. \& Sanger, F. (1964). J. molec. Biol. 8, 835. Moore, S. (1963). J. biol. Chem. 238, 235.

Moustafa, E. (1964). Biochim. biophys. Acta, 91, 421.

Peterson, E. A. \& Sober. H. A. (1962). In Methods in Enzymology, vol. 5, p. 3. Ed. by Colowick, S. P. \& Kaplan, N. O. New York: Academic Press Inc.

Racker, E. (1955). In Methods of Enzymology, vol. 1, p. 500. Ed. by Colowick, S. P. \& Kaplan, N. O. New York: Academic Press Inc.

Schweet, R. S. \& Allen, E. H. (1958). J. biol. Chem. 233, 1104.

Stern, R. \& Mehler, A. H. (1965). Biochem. Z. 842, 400.

Tiselius, A., Hjertén, S. \& Levin, O. (1956). Arch. Biochem. Biophys. 65, 132.

Webster, G. C. (1961). Biochim. biophys. Acta, 49, 141.

Webster, R. E., Engelhardt, D. L. \& Zinder, N. D. (1966). Proc. nat."Acad. Sci., Wash., 55, 155. 